\title{
An uncommon cause for grade 3 primary graft dysfunction after lung transplantation: Takotsubo cardiomyopathy
}

\author{
Akciğer nakli sonrası evre 3 primer greft disfonksiyonunun nadir bir nedeni: \\ Takotsubo kardiyomiyopatisi
}

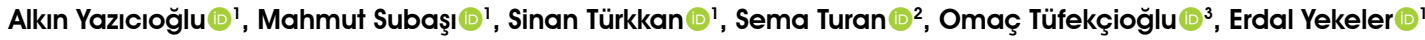 \\ 'Department of Thoracic Surgery and Lung Transplantation, Türkiye Yüksek intisas Training and Research Hospital, Ankara, Turkey \\ 2Department of Intensive Care, Türkiye Yüksek Ihtisas Training and Research Hospital, Ankara, Turkey \\ ${ }^{3}$ Department of Cardiology, Türkiye Yüksek Intisas Training and Research Hospital, Ankara, Turkey
}

\begin{abstract}
Takotusubo cardiomyopathy is an acute, temporary cardiac syndrome which is important for the differential diagnosis of dynamic electrocardiography alterations. Takotsubo cardiomyopathy related to lung transplantation is rather rare in the literature with only two case reports. Our case is the first Takotsubo cardiomyopathy case that manifested in the early period after lung transplantation. In this article, we present a 61-yearold male patient who was performed bilateral sequential lung transplantation for chronic obstructive pulmonary disease. During follow-up, Takotsubo cardiomyopathy was diagnosed, primary graft dysfunction related to cardiomyopathy was observed, and extracorporeal membrane oxygenation was required.
\end{abstract}

Keywords: Cardiomyopathy; graft dysfunction; lung transplantation; Takotsubo.

Takotsubo cardiomyopathy (TTC) is an acute cardiac syndrome characterized by temporary akinesia/ dyskinesia in more than one segment of the left ventricle and dynamic ST/T alterations on electrocardiography (ECG) in the absence of epicardial coronary artery disease, pheochromocytoma, or myocarditis. ${ }^{[1,2]}$ It is particularly important for the differential diagnosis of dynamic ECG alterations following lung transplantation (LuTx), due to common occurrence in patients in the intensive care unit, and is often mistaken for other acute cardiac syndromes with poor prognosis. ${ }^{[3]}$ However, TTC associated with LuTx has been reported in a very limited number of patients to date.

\section{$\ddot{O} Z$}

Takotsubo kardiyomiyopatisi akut, geçici bir kardiyak sendrom olup dinamik elektrokardiyografi değişikliklerinin ayırıcı tanısında önemlidir. Literatürde, akciğer nakli ile ilişkili Takotsubo kardiyomiyopatisi oldukça nadir olup sadece iki olgu sunumu bulunmaktadır. Olgumuz akciğer nakli sonrası erken dönemde ortaya çıkan ilk Takotsubo kardiyomiyopatisi olgusudur. $\mathrm{Bu}$ yazıda, kronik obstrüktif akciğer hastalığı nedeniyle çift taraflı, ardışık akciğer nakli uygulanan 61 yaşında bir erkek hasta sunuldu. Takipte Takotsubo kardiyomiyopatisi tanısı konuldu, kardiyomiyopati ile ilişkili primer greft disfonksiyonu gözlendi ve ekstrakorporeal membran oksijenasyonuna gereksinim duyuldu.

Anahtar sözcükler: Kardiyomiyopati; greft disfonksiyonu; akciğer nakli; Takotsubo.

\section{CASE REPORT}

A 61-year-old male patient was admitted with respiratory insufficiency due to chronic obstructive pulmonary disease (COPD), and was evaluated for LuTx. Pulmonary function test results revealed an obstructive pattern with a forced expiratory volume in one second of $14 \%$, forced vital capacity of $21 \%$, and diffusing capacity of the lungs for carbon monoxide of 34\%. His BODE (Body-Mass Index, Airflow Obstruction, Dyspnea, and Exercise Capacity) index was calculated as 7, whereas the New York Heart Association Functional Class was 3. A quantitative ventilation-perfusion scan revealed left-sided

Received: May 21, 2017 Accepted: October 29, 2017

Correspondence: Alkın Yazıcıoğlu, MD. Türkiye Yüksek İhtisas Eğitim ve Araştırma Hastanesi Göğüs Cerrahisi ve Akciğer Transplantasyonu Kliniği, 06230 Altındağ, Ankara, Turkey. Tel: +90 312 - 4387803 e-mail: yazicioglu.md@gmail.com 

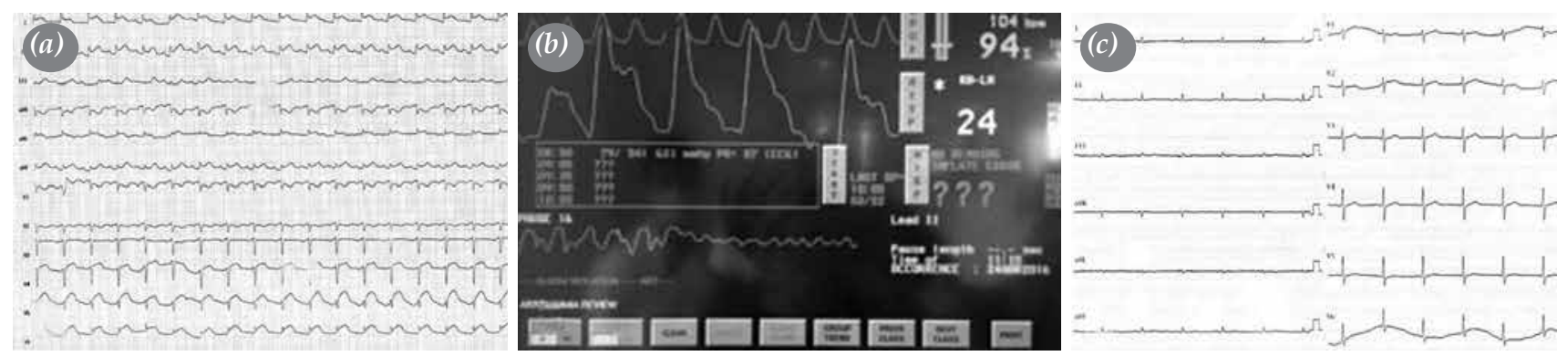

Figure 1. (a) Electrocardiography revealed ST elevation in inferior and lateral leads; however, there was no reciprocal ST depression in other leads. (b) Sustained ventricular tachycardia rhythm was observed; meanwhile, oxygen saturation $\left(\mathrm{SaO}_{2}\right)$ was $94 \%$. (c) Follow-up electrocardiography at sixth month.

predominance with a perfusion of the left lung of $79 \%$ and the right lung of $21 \%$. His medical history was non-specific, except osteoporosis which was treated with calcium and bisphosphonate therapy. A written informed consent was obtained from the patient.

In the cardiac evaluation, echocardiography (ECHO) revealed a pulmonary artery systolic pressure of $40 \mathrm{mmHg}$ and a left ventricular ejection fraction (LVEF) of $65 \%$ without contractility abnormality of the cardiac wall. During the right heart catheterization, pulmonary artery wedge pressure was $10 \mathrm{mmHg}$; systolic, diastolic, and mean pulmonary artery pressures were $30 \mathrm{mmHg}, 13 \mathrm{mmHg}$, and $19 \mathrm{mmHg}$, respectively. Coronary angiography revealed a $50 \%$ atherosclerotic narrowing in the circumflex artery and a stent was implanted. He was admitted to the transplantation waiting list, and six months later, repeated cardiac catheterization confirmed that the stent was intact, and the distal perfusion of circumflex artery was successful without any other atherosclerosis in the coronary arteries.

At seven months in the transplant waiting list, a donor who was compatible with the extended donor criteria was accepted for the patient. The donor's baseline characteristics were as follows: age: 43 years; male; identical blood type; clear chest radiography; 30 pack/year smoking history, no history of thoracic trauma with a ratio of partial arterial pressure of oxygen and fraction of inspired oxygen $\left(\mathrm{PaO}_{2} / \mathrm{FiO}_{2}\right) 349 \mathrm{mmHg}$. Bilateral sequential LuTx was performed without extracorporeal membrane oxygenator (ECMO) support. Ischemic-time was 282 minutes for the right lung and 414 minutes for the left lung. Basiliximab was the preferred induction therapy followed by the initiation of intravenous tacrolimus, prednisolone, and oral mycophenolate mofetil. The cross-match of $\mathrm{T}$ and B-cells was found to be negative.
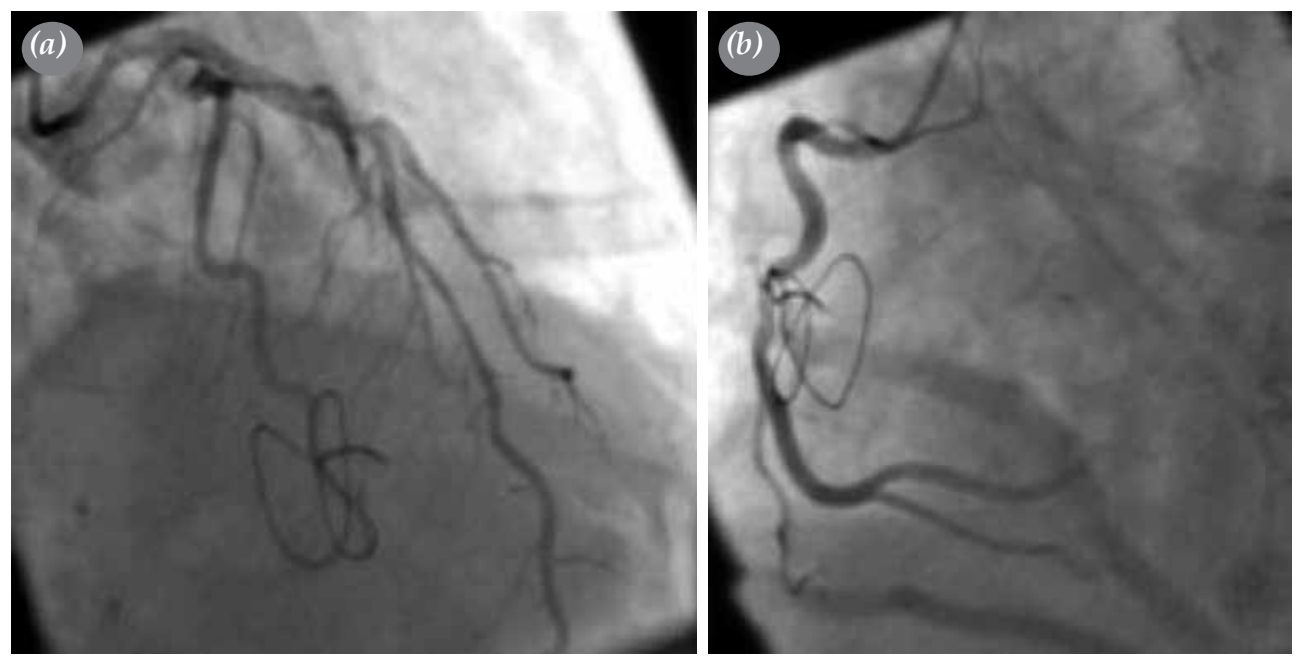

Figure 2. $(\mathbf{a}, \mathbf{b})$ Emergency coronary angiography revealed no recent coronary pathology which would explain for ST alterations in electrocardiography. 


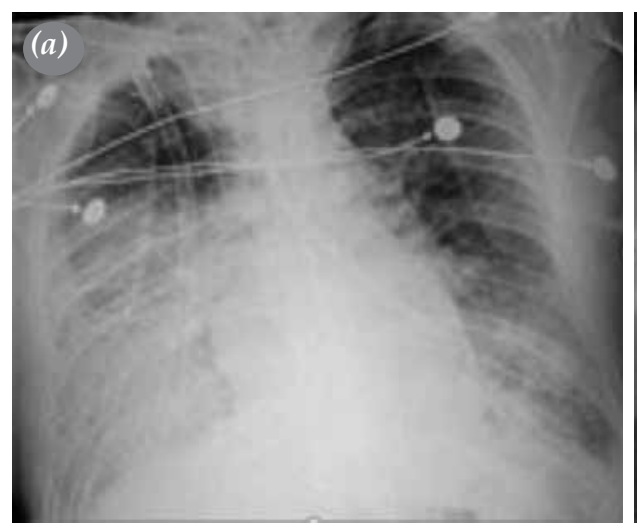

Figure 3. (a) Chest X-ray revealed infiltration on right side during grade 3 primary graft dysfunction period. (b) Follow-up chest X-ray at sixth month.

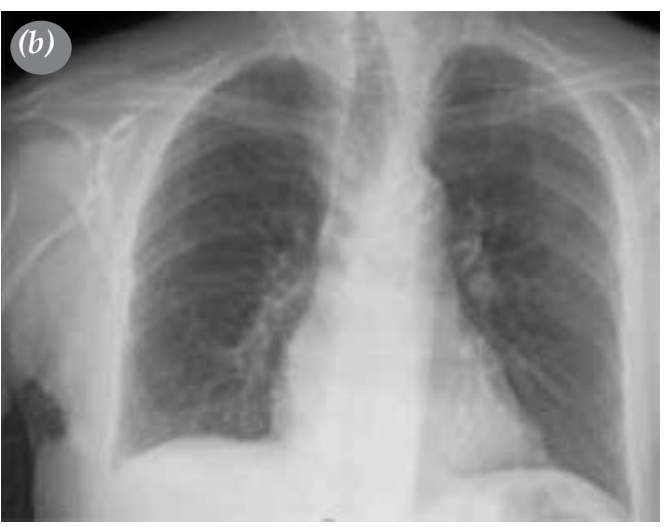

After LuTx, the patient was under follow-up with endotracheal intubation during which he developed recent-onset ST elevation on the cardiac monitor on the postoperative day 1. A 12-lead ECG showed ST elevation in the inferior and lateral leads; however, there was no reciprocal ST depression in the other leads (Figure 1a). The patient, then, developed sustained ventricular tachycardia and returned to normal sinus rhythm following intravenous amiodarone administration (Figure 1b). Bedside ECHO revealed akinetic apical and midventricular segments, and hypokinetic basal segments, and a LVEF of 25 to $30 \%$. The patient underwent emergency coronary angiography; however, there was no recent coronary pathology which would explain for ST alterations (Figure 2a, b). There was a flow pattern in all coronary arteries and sufficient blood supply distal to the stent location. There was no increase in troponin and creatine kinase-muscle and brain (CK-MB) levels which would explain for ST alterations on ECG. The patient developed ventricular fibrillation in the postoperative 36 hours and normal sinus rhythm was restored after defibrillation. Although ECG showed similar findings, there was no increase in troponin and CK-MB levels.

Delaying extubation was considered, and a tracheostomy was performed on the second day. On the third day, chest X-ray revealed infiltration on the right side, and hypoxia on arterial blood gas analysis was added $\left(\mathrm{PaO}_{2} / \mathrm{FiO}_{2}\right.$ ratio decreased to 62 to $82 \mathrm{mmHg}$; oxygen saturation $\left[\mathrm{SaO}_{2}\right]$ was 88 to $94 \%$ ). After a grade 3 primary graft dysfunction (PGD), which was prominent on day 4, arterial blood gas analyses revealed pulmonary impairment with $\mathrm{pH}$ : 7.21, partial pressure of carbon dioxide $\left(\mathrm{pCO}_{2}\right): 76 \mathrm{mmHg}$, partial pressure of oxygen $\left(\mathrm{pO}_{2}\right): 54 \mathrm{mmHg}$, and $\mathrm{SaO}_{2}: 81 \%$. Decline in cardiac LVEF and associated pulmonary edema were suggested to have played a key role in the development of grade 3 PGD (Figure 3a). Therefore, a decision of ECMO insertion was made on the fourth day following transplantation. A peripheral and venoarterial ECMO was initiated, from the right femoral vein through the right subclavian artery. The improvement of the lung functions was sustained, the infiltration on chest X-ray resolved, and peripheral ECMO was weaned on day 7. Six days later (on day 13), the patient was weaned from mechanical ventilation, and tracheostomy was closed on day 14. During cardiac follow-up, ECG alterations resolved in parallel to improvement in the overall condition of the patient, and ST elevations in the inferior and lateral leads returned to the isoelectric line (Figure 1c). The left ventricular wall motions also improved, as evidenced by ECHO examination, and LVEF increased up to $60 \%$ on repeated ECHO on day 15 . We concluded that this clinical presentation was TTC which caused pulmonary edema and disturbances in blood gases through cardiac insufficiency, and played a key role in severe period of PGD, resulting in a need for ECMO. The patient was discharged from the intensive care unit on day 19 and discharged from the hospital on day 34 .

The long-term follow-up revealed normal sinusal rhythm on ECG and repeated ECHO at seventh month following transplantation revealed normal myocardial contractility with an LVEF of 60 to $65 \%$. At one year, he was uneventful without cardiac insufficiency (Figure 3b).

\section{DISCUSSION}

Takotsubo cardiomyopathy, which is also named as broken-heart syndrome, stress-induced cardiomyopathy, and apical ballooning syndrome, is an acute, transient, 
reversible, cardiac wall motion abnormality involving more than one segment of the left ventricle. ${ }^{[1-4]}$ The dynamic ST/T alterations on ECG in the inferior and lateral leads without reciprocal ST depression in the other leads are the typical feature of TTC, in the absence of epicardial coronary artery disease, pheochromocytoma, or myocarditis. ${ }^{[1,2]}$

Although the exact pathophysiological pathway of TTC still remains unclear, catecholamine-mediated myocardial stunning including an acute multi-vessel coronary spasm and coronary microcirculation dysfunction has been suggested to play a key role. ${ }^{[2]}$ Exposure to emotional or physical stress and exaggerated sympathetic activity leads to secretion of excessive catecholamine production and, therefore, it has been suggested that those catecholamine molecules are directly related with myocardium injury. ${ }^{[4]}$ Elevated catecholamine levels decrease the viability of myocytes through cyclic-AMP mediated calcium overload, resulting in contraction band necrosis which is a histological pattern of myocardium injury seen in stress cardiomyopathy. ${ }^{[4]}$

On the other hand, hypoxia and hypercarbia may play an important role in the pathophysiology of TTC using both peripheral and central chemoreceptors. The suggested mechanism for hypoxia may be through peripheral chemoreceptors. ${ }^{[5]}$ These receptors are located in the carotid body and exhibit a sensitive response to hypoxia. In addition, central chemoreceptors are located in the central nervous system, on the ventrolateral medullary surface between the exit of ninth and $10^{\text {th }}$ cranial nerves. Contrary to peripheral chemoreceptors, central chemoreceptors respond to blood gas $\mathrm{pH}$ and hypercarbia. Both systems are related with sympathetic drive and the arterial blood gas alteration stimulates receptors, and this stimulation is in connection with sympathetic system which produces catecholamine. ${ }^{[5]}$ Therefore, the catecholamine secretion, independent from emotional or physical stress, including hypoxia, hypercarbia, and $\mathrm{pH}$ alterations, is thought to play a major role.

Furthermore, TTC is often associated with emotional triggers, physical triggers, and acute respiratory failure. ${ }^{[4,5]}$ In a review by Manfredini et al., ${ }^{[3]}$ TTC was more likely to exist in patients with severe respiratory disease, and patients who needed invasive procedures. This syndrome occurred primarily in females (81.6\%) with an age of approximately 65 years. ${ }^{[3]}$ Also, COPD, asthma, pulmonary embolism, pulmonary hypertension, pneumonia, lung malignancies, and surgery of the lungs, as well as invasive procedures of the lungs, such as rigid bronchoscopy and bronchoalveolar lavage, are considered major pulmonary etiological factors for TTC. ${ }^{[3,4,6]}$

Not only diseases causing respiratory insufficiency or interventions to the lungs, but also emotional or physical stressful conditions may pose a risk for the development of TTC. Organ transplantation is at the top of the conditions in which physical and emotional stress is at the highest level. Organ transplantation is a stressful condition, and several cases of TTC have been reported associated with transplantations such as kidney, liver, and heart. ${ }^{[7-10]}$ To the best of our knowledge, there are only two reports of cases with TTC associated with LuTx in the literature. ${ }^{[5,11]}$ Michel-Cherqui et al. ${ }^{[11]}$ reported a case of TTC diagnosed before LuTx. Ghadri et al. ${ }^{[5]}$ also reported a case of TTC who underwent bilateral LuTx seven years prior and developed respiratory failure. In both cases, hemodynamic instability, hypercarbia, and hypoxia were deemed responsible as stress factors. Our case, on the other hand, is the first who manifested in the early postoperative period after LuTx. As a stress factor, surgical stress can be deemed responsible in this case, similar to that in other cases. Patients with COPD are often composed of patients who live with respiratory insufficiency for several years and have adapted to hypoxia and hypercarbia. In this patient population, peripheral and central chemoreceptors may become desensitized to hypoxia and hypercarbia. We, therefore, consider that hypoxia and hypercarbia did not play a role in the pathogenesis of TTC in our patient. Instead, surgical stress related to LuTx, which is an extensive surgery, and associated catecholamine discharge might have played a role in the underlying etiology. Our case already had TTC and heart failure and, therefore, he developed pulmonary edema, PGD, hypoxia, and hypercarbia.

Furthermore, acute, reversible cardiomyopathy occurring in a LuTx patient may cause development of heart failure. Although this clinical condition is reversible, heart failure would lead to retrograde congestion in the lungs and, thereby, increasing pulmonary pressure of the lungs. Increased pulmonary pressure and congestion may cause pulmonary edema in the early period after LuTx during which fluid balance is delicately managed, leading to more severe graft dysfunction in the early period. Severe PGD results in hypoxia and hypercarbia, increases stress level of the patient, and further worsens cardiomyopathy. Fluid balance, therefore, must be restored in the early period before more profound hypoxia and acidosis develop to break this vicious cycle, and ECMO must be a 
treatment of choice in this setting. In our case, ECMO was used in the early period of PGD before tendency towards acidosis impaired vital findings of the patient and, therefore, pulmonary vascular bed was protected against high pressure and congestion. This therapy provided relief for the lungs during PGD. Cardiac functions also improved during the time gained for the patient and steady increase in the LVEF was confirmed by ECHO.

In conclusion, Takotsubo cardiomyopathy is a rare stress-related type of heart failure and may occur in lung transplantation patients who are exposed to extreme levels of stress. This clinical condition is characterized by dynamic ST/T alterations on electrocardiography and decreased left ventricular ejection fraction on echocardiography; however, cardiac catheterization does not show a filling defect in the coronary arteries. This poses a risk of pulmonary edema associated with cardiac instability in the early period in lung transplantation patients. Pulmonary edema further causes severe primary graft dysfunction in the lungs. A severe primary graft dysfunction alters blood gases and pushes the patient to the critical limits with the development of progressive hypoxia, hypercarbia, and acidosis. In addition, extracorporeal membrane oxygenator and restoring delicate fluid balance are life-saving interventions in the recovery.

\section{Declaration of conflicting interests}

The authors declared no conflicts of interest with respect to the authorship and/or publication of this article.

\section{Funding}

The authors received no financial support for the research and/or authorship of this article.

\section{REFERENCES}

1. Hessel EA. Takotsubo cardiomyopathy and its relevance to anesthesiology: a narrative review. Can J Anaesth 2016;63:1059-74.

2. Akashi YJ, Nef HM, Lyon AR. Epidemiology and pathophysiology of Takotsubo syndrome. Nat Rev Cardiol 2015;12:387-97.

3. Manfredini R, Fabbian F, Giorgi AD, Pala M, Menegatti AM, Parisi C, et al. Heart and lung, a dangerous liaisonTako-tsubo cardiomyopathy and respiratory diseases: A systematic review. World J Cardiol 2014;6:338-44.

4. Landefeld K, Saleh Q, Sander GE. Stress Cardiomyopathy in the Setting of COPD Exacerbation. J Investig Med High Impact Case Rep 2015;3:2324709615612847.

5. Ghadri JR, Bataisou RD, Diekmann J, Lüscher TF, Templin C. First case of atypical takotsubo cardiomyopathy in a bilateral lung-transplanted patient due to acute respiratory failure. Eur Heart J Acute Cardiovasc Care 2015;4:482-5.

6. Kepez A, Yesildag O, Erdogan O, Aktas B. Takotsubo cardiomyopathy in a patient with lung adenocarcinoma. Heart View 2012;13:107-10.

7. Chrapko BE, Tomaszewski A, Jaroszynski AJ, Furmaga J, Wysokinski A, Rudzki S. Takotsubo syndrome in a patient after renal transplantation. Med Sci Monit 2012;18:26-30.

8. Bedanova H, Orban M, Nemec P. Postoperative left ventricular apical ballooning: Transient Takotsubo cardiomyopathy following orthotopic liver transplantation. Am J Case Rep 2013;14:494-7.

9. Tachotti Pires LJ, Cardoso Curiati MN, Vissoci Reiche F, Silvestre OM, Mangini S, Carballo Afonso R, et al. Stressinduced cardiomyopathy (takotsubo cardiomyopathy) after liver transplantation-report of two cases. Transplant Proc 2012;44:2497-500.

10. Behnes M, Baumann S, Borggrefe M, Haghi D. Biventricular takotsubo cardiomyopathy in a heart transplant recipient. Circulation 2013;128:62-3.

11. Michel-Cherqui M, Felten ML, Liu N, Sage E, Devaquet J, Grenet D, et al. Management of takotsubo cardiomyopathy in a lung transplant recipient. Transplantation 2010;90:692-4. 